\title{
Chronic Hepatitis C Virus in the State of Piauí, Northeastern Brazil
}

\author{
Kelson Nobre Veras ${ }^{1}$, Kelson Sousa Jacobina², Vítor Y. Rocha Soares², Marcela Amaral Avelino², Conceição de Maria S.R. \\ Vasconcelos $^{3}$ and José Miguel L. Parente ${ }^{4}$ \\ ${ }^{1}$ Assistant Doctor, Health Municipal Foundation; ${ }^{2}$ Medical Student of Federal University of Piauí; ${ }^{3}$ Assistant Doctor, Hematology and \\ Hemotherapy Center of the State of Piauí; ${ }^{4}$ Supervising Doctor of Medical Residence Program in Gastroenterology, Federal University of Piauí; \\ Teresina, Piauí, Brazil
}

\begin{abstract}
Knowledge of genotype distribution of hepatitis C virus (HCV) has clinical importance due to genotype 1 lower response to treatment compared with genotypes 2 and 3 . The goal of this survey was to describe clinical and laboratorial profiles of patients with chronic hepatitis $\mathrm{C}(\mathrm{CHC})$ in the State of Piauí, as well as to expand the overall awareness of the distribution of HCV genotyping in Northeast of Brazil. A retrospective cross-sectional study was carried out between April 1999 and August 2005. A total of 153 patients were included, 119 (77.8\%) males and 34 $(22.2 \%)$ females; mean age $=48.01 \pm 9.11$ years. We observed a homogeneous distribution between genotypes 1 $(50.0 \%)$ and $3(49.0 \%)$, while the most frequent subtype noticed was $3 a(49.0 \%)$. The mean viral load among patients with subtype $1 \mathrm{~b}(1,232,476 \mathrm{UI} / \mathrm{mL})$ was significantly superior to the subtype $1 \mathrm{a}(391,204 \mathrm{UI} / \mathrm{mL} ; \mathrm{p}=0.010)$ and to the subtype 3a $(594,228 \mathrm{UI} / \mathrm{mL} ; \mathrm{p}=0.047)$. The average levels of gamma-glutamiltransferase of genotype 1 (144 mg/dL) had statistical differences when compared to genotype $3(74 \mathrm{mg} / \mathrm{dL} ; \mathrm{p}=\mathbf{0 . 0 1 4})$. Most patients showed mild to

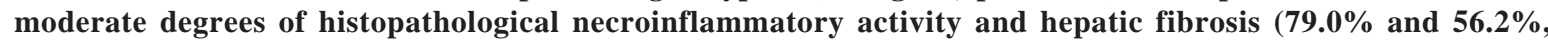
respectively). We concluded that most candidates to treatment of $\mathrm{CHC}$ in the State of Piauí presented with clinically stable hepatic illness; the distribution of genotypes 1 and 3 was virtually homogeneous; and there was no significant demographic or clinical differences among genotypes or subtypes of $\mathrm{HCV}$.

Key-Words: Epidemiology, hepatitis C virus, genotype distribution, chronic hepatitis C.
\end{abstract}

Hepatitis C Virus (HCV) is a single stranded RNA virus belonging to the Flaviridae family [1]. It is possible to classify HCV in genotypes (designated by Arabic numerals) and subtypes (designated by lower cases) using a method of amplification by reverse transcriptase-polymerase chain reaction (RT-PCR) of the NS5 region of HCV genome, followed by analysis with restriction fragment length polymorphism (RFLP) [2]. Nowadays, there are six main known genotypes designated by numbers 1 to 6; however, infection usually occurs by a single genotype. The identification of the genotypes has therapeutic and clinical implications due to a lower response to treatment shown by genotype 1 when compared with genotypes 2 and 3 [3-6].

World distribution of those several genotypes has some peculiarities. Genotypes 1, 2 and 3 are spread worldwide, although in different proportions according to the geographic area. Genotype 4 is restricted to Africa and Middle East, while genotypes 5 and 6 are uncommon, mainly encountered in South Africa and Hong Kong, respectively [7-10].

In the Northeast Region of Brazil, studies from the states of Bahia, Ceará and Rio Grande do Norte indicate that the main genotypes of HCV are types 1 and 3 [11-16]. Even though this genotype distribution resembles that found in Brazil as a whole, in fact these surveys had frequently presented only selective studies of specific groups such as drugs users,

Received on 29 October 2008; revised 23 February 2009.

Address for correspondence: Dr. Kelson Nobre Veras. Rua Taumaturgo de Azevedo 3443, apto. 1201. Zip code: 64001-340 Teresina, Piauí Brazil. E-mail: kelsonveras@hotmail.com.

The Brazilian Journal of Infectious Diseases

2009;13(2):125-129. (C) 2009 by The Brazilian Journal of Infectious Diseases and Contexto Publishing. All rights reserved. hemophiliacs, patients with chronic kidney disease and blood donors [15-21]. So, population surveys of HCV genotypic distribution are very needed in Brazil in order to know the real characteristics of this disease in this large country, as it was pointed out by Focaccia et al. [11]

The goal of this study was to describe clinical and demographic profile of patients with chronic hepatitis $\mathrm{C}$ in the state of Piaui as well as to enlarge the overall awareness of genotypic distribution of HCV in Northeast of Brazil.

\section{Material and Methods}

The Secretary of Health of Piauí offers free treatment to all patients with chronic hepatitis $C$ who resides in Piauí. Since, data presented in this study can be considered as representative of persons with chronic hepatitis $C$ in this area of our country.

This cross-sectional study was reviewed and approved by the Institutional Review Board of the Federal University of Piauí, Brazil. The study was carried out between April 1999 and August 2005.

Exclusion criteria were lack of laboratorial evidence of hepatitis $C$ virus infection by immunological and/or polymerase chain reaction methods and hepatitis B virus or human immunodeficiency virus coinfection. Data from 153 patients were enrolled in the study. No patient had ever been treated before and only 12 patients had chronic kidney disease.

The following variables were analyzed: age, gender, genotype and subtype, viral load, serum aminotransferases (ALT and AST), total and direct bilirrubin, total protein, gammaglutamiltransferase $(\gamma \mathrm{GT})$, creatinine, albumin, thyroid stimulant hormone, platelet count. Histopathological assays of liver specimens obtained by aspirative needle biopsies were analyzed for grading periportal or periseptal necroinflamatory 
activity and fibrosis according to Chronic Hepatitis Classification of Pathology and Hepatology Brazilian Societies [22]. Not all variables were available for all patients.

\section{Statistical Analysis}

The univariate Pearson's chi-square $\left(\chi^{2}\right)$ and Fisher's exact tests were used to measure differences in overall rates. Student's $t$-test and Levene's test were used to compare differences among continuous variables. The odds ratio (OR) and $95 \%$ confidence intervals (CI) were estimated. P values < $5 \%$ were statistically significant. Data were analyzed with the Statistics Packages of SPSS version 11.0 software (SPSS, Inc., Chicago, ILL) and MedCalc Version 9.3.2.0.

\section{Results}

A total of 153 patients were enrolled: 119 (77.8\%) males and 34 (22.2\%) females. Age varied between 16 and 74 years with mean \pm SD age of $48.01 \pm 9.11$ years. Women were older than men with mean \pm SD age of $52.76 \pm 7.56$ and $46.51 \pm 9.06$ years, respectively $(\mathrm{p}=0.001)$.

Genotypes 1 (50.0\%) and 3 (49.0\%) had a similar distribution, while subtype 3a (49.0\%) was the most frequent subtype observed. Amongst patients with genotype 1, thirty one (26.0\%) presented with subtype $1 \mathrm{a}$ and 28 (24.0\%) with subtype $1 \mathrm{~b}$ (Table 1 ).

Table 1. Patients with Chronic Hepatitis C in the state of Piauí, Brazil, According to Genotyping.

\begin{tabular}{ll}
\hline Genotypes and Subtypes & Frequency N (\%) \\
\hline Genotypes 1 & $59(50.0)$ \\
1a & $31(26.0)$ \\
1b & $28(24.0)$ \\
Genotypes 3 & $57(49.0)$ \\
3a & $57(49.0)$ \\
Genotypes 2 & $1(1.0)$ \\
2b & $1(1.0)$ \\
Total (n) & $117(100)$ \\
\hline
\end{tabular}

Laboratorial data are shown in Table 2. The mean level of viral load of patients with subtype $1 \mathrm{~b}(1,232,476 \mathrm{IU} / \mathrm{mL})$ was significantly higher to that of subtype $1 \mathrm{a}(391,204 \mathrm{IU} / \mathrm{mL} ; \mathrm{p}=$ $0.010)$ and to that of subtype 3a $(594,228 \mathrm{IU} / \mathrm{mL} ; \mathrm{p}=0.047)$. The mean levels of $\gamma \mathrm{GT}$ showed statistical differences among patients with genotype 1 when they were compared with patients with genotype $3(144 \mathrm{mg} / \mathrm{dL}$ and $74 \mathrm{mg} / \mathrm{dL}$, respectively; $p=0.014$ ). There were no statistically significant differences within other laboratorial exams between patients with subtypes 1a, $1 \mathrm{~b}$ and $3 \mathrm{a}$ (Table 02 ).

Histopathology of hepatic biopsies showed that most patients (79.0\%) presented mild to moderate degrees of necroinflamatory activity, while $56.7 \%$ presented with mild to moderate degrees of fibrosis (Table 3). The only significant difference found between genotypes and degree of fibrosis was a greater risk to septal fibrosis - F3 - in genotype 3 (Table 4).

\section{Discussion}

The present study indicates that HCV genotypes 1 and 3 were the most prevalent with an identical distribution, while genotype 2 was found only in one patient. In the state of Ceará, a neighboring state of Northeastern Brazil, a previous study also found a similar distribution, i.e., $50.0 \%$ for genotypes 1 and 3 among 22 patients under hemodialysis [15]. However, our results differ from the study carried out by Focaccia et al., involving a greater number of patients from several regions of Brazil, which found $64.0 \%$ infected with genotype 1, and 33.0\% for genotype 3 [11]. Similarly, Vasconcelos et al., also in the state of Piauí, found $74.1 \%$ and $61.0 \%$ for genotype 1 and $22.2 \%$ and $36.0 \%$ for genotype 3 , among patients under hemodialysis and blood donors, respectively [23].

Other issues indicate a predominance of genotype 1 in Southeastern Region of Brazil [11,15,17,18,24,25]. Its prevalence is around $70.0 \%$ in the states of Rio de Janeiro and São Paulo, and 84.1\% in Minas Gerais [18]. In Northeastern Region, many surveys were carried out in the state of Bahia involving a great number of cases. The genotypic variation follows the pattern of the rest of Brazil, with genotype 1 corresponding about $70.0 \%$ of the individuals infected [1113]. On the other hand, some studies from South Region indicate a profile of genotypic distribution closer to that found in our study. There, genotype 3 has already been described as the predominant genotype in the state of Rio Grande do Sul [25]. Taken together, data from Paraná and Rio Grande do Sul indicate a major role for genotype 3 in South Region (44\% of cases) as compared with other regions of Brazil, though genotype 1 still predominates (51\% of patients) [11].

Genotype 3 has been associated with transmission through illicit injection-drug use. In Rio de Janeiro, genotype 3 was more frequently found between intravenous drugs users as compared with blood donors and hemophilic patients [15]. In France, besides an independent association between genotype 3 and injection-drug use, its frequency increased between 1970 to 1990, when the ratio of infected patients rose from $35.1 \%$ to $54.8 \%$ [26]. The present study is not intended to analyze the association between genotypes and ways of transmission of hepatitis $\mathrm{C}$ virus. However, there are many anecdotal accounts of medical use of intravenous stimulants in this population, whose users shared syringes or used inadequately sterilized glass syringes. Thus, it can be deduced that this habit could have contributed to a large dissemination of genotype 3 in our region as other authors have already suggested [17,27].

The mean age of our patients was about 48 years, similar to what has been described in other studies in Brazil $[11,13,17,24,28]$. There was no difference between mean ages in patients with genotypes 1 and 3 (48.0 and 47.7 years old, respectively), similar to what was found by Bassit et al. in São Paulo [24]. In a survey from Bahia, the average age of the patients infected with genotype 3 was inferior to age of patients with genotype 1 (38 and 55 years, respectively) [12]. In our study, ages of females patients were higher than those of 
Table 2. Patients with chronic hepatitis $\mathrm{C}$ in the state of Piauí, Brazil, according to biochemistry, genotypes and subtypes aspects.

\begin{tabular}{|c|c|c|c|c|c|c|}
\hline Variables & 1 & $\begin{array}{l}1 \mathrm{a} \\
\text { Mean } \pm \text { SD (n) }\end{array}$ & $\begin{array}{l}\text { lb } \\
\text { Mean } \pm \text { SD (n) }\end{array}$ & $\begin{array}{l}\text { 3a } \\
\text { Mean } \pm \text { SD (n) }\end{array}$ & Mean \pm SD & Pvalue \\
\hline Viral Load (UI/mm³) & $\begin{array}{l}781,062 \pm \\
974,778,3(41)\end{array}$ & $\begin{array}{l}391,204,4 \pm \\
412,658,2(22)\end{array}$ & $\begin{array}{l}1,232,476 \pm \\
1,229,638,9(19)\end{array}$ & $\begin{array}{l}594,227,6 \pm \\
720,985,9(40)\end{array}$ & $\begin{array}{l}647,480,07 \pm \\
815.839,04\end{array}$ & $\begin{array}{l}0.010^{\dagger} \\
0.047^{9}\end{array}$ \\
\hline AST (U/l) & $88.7 \pm 51.2(58)$ & $91.1 \pm 57.9(31)$ & $85.9 \pm 43(27)$ & $93.6 \pm 52.3(56)$ & $94.51 \pm 57.27$ & $>0.050^{*}$ \\
\hline $\operatorname{ALT}(\mathrm{U} / \mathrm{l})$ & $121.3 \pm 73(59)$ & $122.3 \pm 79.1(31)$ & $120.3 \pm 67,2(28)$ & $121.12 \pm 62.5(56)$ & $122.55 \pm 71.70$ & $>0.050^{*}$ \\
\hline Totalbilirrubin(mg\%) & $1.3 \pm 0.9(40)$ & $1.3 \pm 0.9(23)$ & $1.3 \pm 1(17)$ & $1.1 \pm 0.5(40)$ & $1.20 \pm 0.83$ & $>0.050^{*}$ \\
\hline Directbilirrubin (mg\%) & $0.6 \pm 0.5(40)$ & $0.5 \pm 0.5(23)$ & $0.6 \pm 0.6(17)$ & $0.4 \pm 0.2(40)$ & $0.54 \pm 0.57$ & $>0.050^{*}$ \\
\hline Total protein (g\%) & $7.9 \pm 0.8(38)$ & $7.3 \pm 0.7(21)$ & $6.9 \pm 0.9(17)$ & $7.0 \pm 1(39)$ & $7.05 \pm 0.95$ & $>0.050^{*}$ \\
\hline Albumin (g\%) & $4.1 \pm 0.6(41)$ & $4.1 \pm 0.6(24)$ & $4.2 \pm 0.7(17)$ & $4.2 \pm 0.6(45)$ & $4.15 \pm 0.67$ & $>0.050^{*}$ \\
\hline Gama-GT(U/L) & $143.8 \pm 140(34)$ & $141.6 \pm 151.6(19)$ & $146.5 \pm 129.1(15)$ & $74.5 \pm 75.2(33)$ & $108.88 \pm 109.49$ & $\begin{array}{l}0.014^{\S} \\
0.037^{\#}\end{array}$ \\
\hline Platelets (U/mm³) & $\begin{array}{l}174,176.5 \pm \\
46,195.1(51)\end{array}$ & $\begin{array}{l}167,620.7 \pm \\
47,465.4(29)\end{array}$ & $\begin{array}{l}182,818.2 \pm \\
44,038.6(22)\end{array}$ & $\begin{array}{l}178,485.7 \pm \\
66,307.4(49)\end{array}$ & $\begin{array}{l}178,158.91 \pm \\
62,221.31\end{array}$ & $0.050^{*}$ \\
\hline $\mathrm{TSH}\left(\mathrm{U} / \mathrm{mm}^{3}\right)$ & $1.6 \pm 1.1(35)$ & $1.7 \pm 1.2(21)$ & $1.3 \pm 0.8(14)$ & $1.6 \pm 0.8(40)$ & $1.59 \pm 0.91$ & $>0,050^{*}$ \\
\hline
\end{tabular}

*Comparison between subtypes and between genotypes; ${ }^{\dagger}$ Comparison between subtypes 1a and 1b; " Comparison between subtypes $1 \mathrm{~b}$ and $3 \mathrm{a}$; ${ }^{\S}$ Comparison between genotypes 1 and 3; "Comparison between subtypes 1a and 3a; Gama-GT = gamaglutamitransferase; AST = aspartate aminotransferase; ALT = alanine aminotransferase; TSH = thyroid-stimulating hormone.

Table 3. Patients with chronic hepatitis C in the state of Piauí, Brazil, according to histological features.

\begin{tabular}{lll}
\hline Histological Features & Frequency & Percentage (\%) \\
\hline Fibrosis & & \\
F0 & 21 & 18.6 \\
F1 & 23 & 20.4 \\
F2 & 20 & 17.7 \\
F3 & 28 & 24.8 \\
F4 & 21 & 18.6 \\
Total (n) & 113 & 100.0 \\
Periportal Necroinflamatory Activity & \\
Mild (0 to 2) & 21 & 20.0 \\
Moderate (3) & 62 & 59.0 \\
Severe (4) & 22 & 21.0 \\
Total (n) & 105 & 100.0 \\
\hline
\end{tabular}

males (53 and 46 years, respectively; $p=0.001$ ). These data are in accordance with results found in another Brazilian study.[11] Looking at gender, we found a predominance of males (78.0\%), and this result is similar to that observed in other regions of Brazil [11,13,17,23,24]. There was no association between genotype and gender, and this finding is in agreement with other studies in national literature [13,24].

The mean levels of bilirrubins, total proteins, albumin and platelets were within normal ranges, showing a profile of patients with compensated hepatic illness. Mean levels of serum aminotransferases and gamaglutamiltransferase of our patients revealed only mild changes as it is common in patients with CHC $[29,30]$. According to genotyping, only patients infected with genotype 1 showed high mean levels of gamaglutamiltransferase ( $p=0.019)$. Gamaglutamiltransferase is known as a sensible but nonspecific marker of hepatobiliar

Table 4. Association between viral genotypes and hepatic histopathological findings.

\begin{tabular}{|c|c|c|c|c|c|}
\hline Hepatic histopathology & Gentotype 1 & Genotype 3 & Total & $\begin{array}{l}\text { Odds ratio } \\
\text { (95\% confidence interval) }\end{array}$ & Pvalue \\
\hline \multicolumn{6}{|l|}{ Fibrosis } \\
\hline F0 & $11(64.7)$ & $6(35.3)$ & 17 & $2.17(0.73-6.42)$ & $>0.05$ \\
\hline F1 & $11(50)$ & $11(50)$ & 22 & $1.05(0.41-2.71)$ & $>0.05$ \\
\hline F2 & $12(66.7)$ & $6(33.3)$ & 18 & $2.43(0.83-7.10)$ & $>0.05$ \\
\hline F3 & $7(28)$ & $18(72)$ & 25 & $0.31(0.11-0.82)$ & 0.021 \\
\hline F4 & $8(44.4)$ & $10(55.6)$ & 18 & $0.80(0.29-2.23)$ & $>0.05$ \\
\hline Total & 49 & 51 & 100 & & \\
\hline \multicolumn{6}{|c|}{ Periportal necroinflamatory activity } \\
\hline Mild $(0-2)$ & $9(50)$ & $9(50)$ & 18 & $1.01(0.39-3.03)$ & $>0.05$ \\
\hline Moderate (3) & $24(44.4)$ & $30(55.6)$ & 54 & $0.69(0.30-1.57)$ & 0.41 \\
\hline Severe (4) & $12(57.1)$ & $9(42.9)$ & 21 & $1.58(0.60-4.20)$ & 0.46 \\
\hline Total & 45 & 48 & 93 & & \\
\hline
\end{tabular}


illness [31], and it is associated to advanced hepatic fibrosis [17]. However, there was no association between genotype 1 and degree of fibrosis in this study. Therefore, we could not explain the raised levels of gamaglutamiltransferase found in genotype 1 in our survey. Other possible confusing variables that had not been evaluated in this study, particularly intake of alcohol [32], could explain the results presented by us. Different from Codes et al. [13], we did not find thyroid dysfunction among patients with HCV genotypes 1 and 3.

The majority of our patients had mild to moderate degrees of periportal or perisseptal necroinflammatory activities, i.e., between 0 and 3 according to classification of Brazilian Societies of Pathology and Hepatology, while half of them presented with mild to moderate degrees of fibrosis. Similar histopathological profiles of patients with chronic hepatitis C was shown in other regions of Brazil [13,17,23,25]. In spite of this, some patients had cogitated their treatment only in advanced phase of fibrosis, and hepatic cirrhosis was already present in almost $20.0 \%$ of them before beginning of treatment.

No national study had found an association between degree of fibrosis and genotypes of HCV. In fact, this topic seems to be settled as well as that genotypes do not predict severity of hepatitis $C[7,33]$. Nevertheless, our findings showed a significant lower risk to a high degree hepatic fibrosis (F3) with genotype 1 as compared with genotype 3 $(\mathrm{OR}=0.31$; CI: 0.11 to $0.82 ; \mathrm{p}=0.02)$. However this is a subgroup analysis of a small number of patients.

A caveat in our survey is that genotype frequencies may vary when comparing population and referral center genotypic distribution data as ours. Zarife et al. [34] found in Salvador that genotype 3 was the most common genotype (53.3\%), followed by genotypes 1 (40\%) and 2 (6.7\%). However, when comparing these observations with data from hospital and ambulatory patients from the same city, genotype 1 was the most frequent, followed by genotypes 3 and 2 .

In conclusion, our analysis of candidates to treatment of CHC in the state of Piauí, Northeast of Brazil, showed preponderantly male patients, in the course of the fifth decade of life, presenting clinically compensated illness; the majority had mild to moderate degrees of histological activity and fibrosis; genotypes 1 and 3 were practically homogeneous, and genotype 2 was rare; significant demographic and clinical differences had not been shown between genotypes.

\section{References}

1. Robertson B., Myers G., Howard C., et al. Classification, nomenclature, and database development for hepatitis $\mathrm{C}$ virus (HCV) and related viruses: proposals for standardization. Arch Virol 1998;143:2493-2503.

2. Simmonds P., Holmes E.C., Cha T.A., et al. Classification of hepatitis $\mathrm{C}$ virus into six major genotypes and a series of subtypes by phylogenetic analysis of the NS-5 region. J Gen Virol 1993;74:2391-9.

3. McHutchison J.G., Gordon S.C., Schiff E.R., et al. Interferon alpha$2 \mathrm{~b}$ alone or in combination with ribavirin as initial treatment for chronic hepatitis C. Hepatitis Interventional Therapy Group. N Engl J Med 1998;339:1485-92.
4. Poynard T., Marcellin P., Lee S.S., et al. Randomized trial of interferon alpha-2b plus ribavirin for 48 weeks or for 24 weeks versus interferon alpha-2b plus placebo for 48 weeks for treatment of chronic infection with hepatitis $\mathrm{C}$ virus. International Hepatitis Interventional Therapy Group (IHIT). Lancet 1998;352:1426-32.

5. Manns M.P., McHutchison J.G., Gordon S.C., et al. PEG-interferon alfa-2b in combination with ribavirin compared to interferon alfa-2b plus ribavirin for initial treatment of chronic hepatitis C: a randomized trial. Lancet 2001;358:958-65.

6. Fried M., Shiffman M.L., Reddy K.R., et al. Peginterferon alfa-2a plus ribavirin for chronic hepatitis $\mathrm{C}$ virus infection. N Engl J Med 2002; 347:975-82.

7. Hoofnagle J.H. Course and outcome of hepatitis C. Hepatology 2002;36(5B):21-9.

8. Smuts H.E., Kannemeyer J. Genotyping of hepatitis C virus in South Africa. J Clin Microbiol 1995;33:1679-81.

9. Songsivilai S., Kanistanon D., Dharakul T. A serotyping assay for hepatitis $C$ virus in Southeast Asia. Clin Diagn Lab Immunol 1998;5:737-9.

10. Zein N.N. Clinical significance of hepatitis C virus genotypes. Clin Microbiol Rev 2000;13:223-35.

11. Focaccia R., Baraldo D.C.M., Ferraz M.L.G., et al. Demographic and anthropometrical analysis and genotype distribution of chronic hepatitis $\mathrm{C}$ patients treated in public and private reference centers in Brazil. Braz J Infect Dis 2004;8(5):348-55.

12. Parana R., Vitvitski L., Berby F., et al. HCV infection in northeastern Brazil: unexpected high prevalence of genotype $3 \mathrm{a}$ and absence of African genotypes. Arq Gastroenterol 2000;37(4):213-6.

13. Codes L., Freitas L.A.R., De Santos-Jesus R., et al. Comparative study of Hepatitis $C$ virus genotypes 1 and 3 in Salvador, Bahia. Braz J Infect Dis 2003;7(6):409-17.

14. Silva L.K., Parana R., Souza S.P., et al. Hepatitis C virus genotypes in a Northeastern area of Brazil. Am J Trop Med Hyg 2000;62:257-60.

15. Oliveira M.L.A., Bastos F.I., Sabino R.R., et al. Distribution of HCV genotypes among different exposure categories in Brazil. Braz J Med Biol Res 1999;32(3):279-82.

16. Martins R.M.B., Vanderborght B.O.M., Yoshida C.F.T. Hepatitis $\mathrm{C}$ virus genotypes among blood donors from different regions of Brazil. Mem Inst Oswaldo Cruz 1998;93(3):299-300.

17. Silva G.F., Nishimura N.F., Coelho K.I.R., et al. Grading and staging chronic hepatitis $\mathrm{C}$ and its relation to genotypes and epidemiological factors in Brazilian blood donors. Braz J Infect Dis 2005;9(2):142-9.

18. Oliveira G.C., Carmo R.A., Rocha M.O.C., et al. Hepatitis C virus genotypes in hemophiliacs in the state of Minas Gerais, Brazil. Transfusion 1999;39(11):1194-9.

19. Carmo R.A., Oliveira G.C., Guimarães M.D.C., et al. Hepatitis C virus infection among Brazilian hemophiliacs: a virological, clinical and epidemiological study. Braz J Med Biol Res 2002;35(5):589-98.

20. Carneiro M.A.S., Martins R.M.B., Teles S.A., et al. Hepatitis C prevalence and risk factors in hemodialysis patients in Central Brazil: a survey by polymerase chain reaction and serological methods. Mem Inst Oswaldo Cruz 2001;96(6):765-9.

21. Busek S.U., Babá E.H., Tavares Filho H.A., et al. Hepatitis C and hepatitis $\mathrm{B}$ virus infection in different hemodialysis units in Belo Horizonte, Minas Gerais, Brazil. Mem Inst Oswaldo Cruz 2002;97(6):775-8.

22. Gayotto L.C.C. e Comitê SBP/SBH. Visão histórica e consenso nacional sobre a classificação das hepatites crônicas. GED 2000; 19:137-40.

23. Vasconcelos C.M.S.R., Monte S.J.H., Yoshida C.F.T. Prevalência do anticorpo para o vírus da hepatite $\mathrm{C}$ e distribuição do seu genótipo em doadores voluntários de sangue e em pacientes submetidos à hemodiálise em Teresina, Piauí. 2001, 90 pág. Dissertação de Mestrado. UFPI. Teresina. 
24. Bassit L., Da Silva L.C., Ribeiro-dos-Santos, G., et al. Chronic hepatitis $\mathrm{C}$ virus infections in Brazilian patients: association with genotypes, clinical parameters and response to long term alpha interferon therapy. Rev Inst Med Trop S Paulo 1999;41(3):183-9.

25. Alves A.V., Azevedo A.P.C., Perin C., et al. Tratamento de pacientes com hepatite crônica pelo vírus C com interferon-alfa e ribavirina: a experiência da Secretaria de Saúde do Rio Grande do Sul. Arq Gastroenterol 2003;40(4):227-32.

26. Bourlière M., Barberin J.M., Rotily M., et al. Epidemiological changes in hepatitis C virus genotypes in France: evidence in intravenous drug users. J Viral Hepat 2000; 9(1):62-70.

27. Parana R., Lyra L., Trepo C. Intravenous vitamin complexes used in sporting activities and transmission of HCV in Brazil. Am J Gastroenterol 1999;94(3):857-858.

28. Araújo E.S.A., Cavalheiro N.P., Leitão R.M.C., et al. Hepatitis C viral load does not predict disease outcome: going beyond numbers. Rev Inst Med Trop S Paulo 2002;44(2):71-8.
29. Shakil A.O., Conry-Cantilena C., Alter H.J., et al. Volunteer blood donors with antibody to hepatitis C virus: clinical, biochemical, virologic, and histologic features. The Hepatitis C Study Group. Ann Intern Med 1995; 7:123:330.

30. Giannini E., Botta F., Fasoli A., et al. Increased levels of $\gamma \mathrm{GT}$ suggest the presence of bile duct lesions in patients with chronic hepatitis C. Dig Dis Sci 2001;46(3):524-9.

31. Pratt D.S., Kaplan M.M. Evaluation of abnormal liver-enzyme results in asymptomatic patients. N Engl J Med 2000;342:1266-71.

32. Conigrave K.M., Degenhardt L.J., Whitfield J.B., et al. On behalf of the WHO/ISBRA Study Group. CDT, GGT, and AST as markers of alcohol use: The WHO/ISBRA Collaborative Project. Alcohol Clin Exp Res 2002;26(3):332-9.

33. Strader D.B., Wright T., Thomas D.L., Seeff L.B. Diagnosis, management, and treatment of hepatitis C. Hepatology 2004;39(4):1147-71.

34. Zarife M.A.S., Silva L.K., Silva M.B.S., et al. Prevalence of hepatitis $\mathrm{C}$ virus infection in northeastern Brazil: a population-based study. Trans R Soc Trop Med Hyg 2006;100:663-8. 